\title{
Drought tolerance and regrowth capacity revealed in the Festuca-Lolium complex
}

\author{
V. CERNOCH ${ }^{1}$ and D. KOPECKY ${ }^{2 *}$ \\ DLF Seeds, Fulnecká 95, Hladké Životice, CZ-74247, Czech Republic ${ }^{1}$ \\ Institute of Experimental Botany, Czech Academy of Sciences, Centre of the Region Haná for Biotechnological \\ and Agricultural Research, Olomouc, CZ-77900, Czech Republic ${ }^{2}$
}

\begin{abstract}
The climate change appears to have accelerated in recent years, and more changes are envisaged in the near future. With this in mind, breeders should consider the choices of materials to be used in breeding for the future to potentially mitigate the impacts of changes. In forage grasses, a special attention has to be paid to drought and heat tolerance. Here, in a screening trial of numerous accessions, we investigated drought tolerance and after-drought recovery rates among the species of the Festuca-Lolium complex, including cultivars and breeding materials as well as various ecotypes of wild species. Experimental trials were done using rainout shelters during three successive years $2017-2019$. The most drought tolerant genotypes belonged to the species $F$. glaucescens and $F$. mairei, followed by $F$. atlantigena, F. arundinacea, and some genotypes of $F$. pratensis. These genotypes should be considered as suitable candidates for intergeneric hybridization with L. multiflorum and L. perenne. O ur test shows that Festulolium krasanii ( L. multiflorum $\times$ F. ar undinacea) is a good candidate to replace pure tall fescue (F. arundinacea) stands. It has the same or similar drought tolerance and drought recovery as tall fescue and at least some cultivars are known for their high feeding value, unlike tall fescue itself. A large variability for drought tolerance and recovery rates in Fl. braunii (the L. multiflorum $\times$ F. pratensis hybrid) and $F$ l. loliaceum (the L. perenne $\times F$. pratensis hybrid) permit selection of genotypes that can outperform the original L. multiflorum and L. perenne.
\end{abstract}

Additional key words: intergeneric hybridization, climatic adaptation, Festulolium krasanii, Festulolium braunii, Festulolium loliaceum.

\section{Introduction}

Plant production is the sector presumed to be the most seriously affected by projected climate changes in future. In general, climate change will likely have a negative impact on plant production, thereby threatening global food security (Cai et al. 2015). Climate change with increased temperatures will be further exacerbated by longer growing periods of crops with increased water requirements, soil erosion, faster desertification in places like Mediterranean areas, pest pressures and the risk of increased salinity (Eitzinger et al. 2013). Apart from long-term trends and shifts of climatic variables, such as precipitation and temperature, climate change projections also predict increasing frequency, intensity, and duration of extreme events, such as drought, flood, and heat waves lasting from a few weeks to several months. The frequency of such events has increased over the past 60 years and the frequency and intensity of these events will presumably be amplified even more in the future. Trnka et al. (2013) predicted that the probability of xeric years (i.e., years when soil is dry throughout the profile during most of the summer) in Central Europe will increase from "very rare" to events occurring at least once every 20 years by 2050 and once every 10 years by 2100 .

It is evident, that the occurrence of extreme events, especially droughts, will play a key role in future agriculture and farming and, consequently, food production and food security (Eitzinger et al. 2013). Drought causes considerable losses in agricultural production through multiple factors such as water deficit, heat stress, and extensive spread of insects during periods of drought (Eitzinger et al. 2013). Zahradníček et al. (2015) reported that drought in summer 2012 caused severe reduction of winter crop yields such as winter wheat in the important eastern cereal-producing regions in the Czech Republic to

Submitted 16 April 2020, last revision 15 June 2020, accepted 15 June 2020.

Acknowledgements: We would like to thank Prof. Adam J. Lukaszewski (University of California, Riverside) for his critical reading and valuable comments. This research was partially funded by the Czech Science Foundation (grant awards 20-10019S) and by the European Regional Development Fund OPVVV project 'Plants as a tool for sustainable development' number CZ.02.1.01/0.0/0.0/16 019/0000827 supporting Excellent Research at CRH.

* Corresponding author; e-mail: kopecky@ueb.cas.cz 
the lowest absolute levels since 1961 (which is when the database was first established). Droughts are expected to intensify in the future in many regions, including Central and Southern Europe, the Mediterranean area, central North America, Australia, southern Africa, and northeast Brazil (Intergovernmental Panel on Climate Change 2012).

In general, water availability is the key factor through which climate change affects crop yields. To mitigate the negative effects of climate change, and especially of uneven distribution of precipitation, increased temperature and more frequent and severe periods of drought, immediate actions are required in many regions of the world (Cai et al. 2015). Various adaptations and adequate policies are already necessary to cope with the impact of climate change, especially for agricultural risk management. Reliable recommendations about early risk recognition and the implementation of anticipatory adaptation strategies are more effective and less costly than forced, last-minute, or emergency adaptations (Eitzinger et al. 2007). However, the coping capacity of some countries (e.g. Czech Republic) is limited by a lack of suitable environments, such as long-lasting snow peaks, glaciers, natural lakes, and/or aquifers. Besides governmental input, farmers can modify their crop mixes, the timing of their agricultural activities, and the irrigation efficiency. The development and utilization of cultivars with improved abiotic-stress tolerance is one of the most suitable ways to cope with climate changes and mitigate their negative impacts. This will be extremely important especially in the areas which already experience the most severe increase of extremes including drought and heat waves, such as in the Mediterranean area and the Central and Eastern Europe (Zhao et al. 2015).

Grasslands cover around $30 \%$ of the agricultural land in Europe (Kipling et al. 2016). Apart from their ecological role in the maintenance of biodiversity, anti-erosion capacity, and very important carbon sequestration, they are the main source of feed intake for livestock in many regions (O'Mara 2012). Changes in their productivity and quality due to changes in water availability and increased temperature may strongly affect animal reproductive rates (Harle et al. 2007). Thus, drought tolerance is becoming one of the main tasks in the breeding of forage and turf grasses for future conditions. Among grasses, ryegrass species belong to the agriculturally most important. They are widely used for permanent and temporary pastures and meadows as well as for hay and silage production. However, their future utilization will be limited by their generally poor drought tolerance. One would assume that identification of ecotypes with outstanding drought tolerance and their introgression into elite cultivars would mitigate the impact of climate change (Hulke et al. 2007). However, Bothe et al. (2018) reported that drought tolerance in various ecotypes of perennial ryegrass is lower than that of commercial cultivars. On the other hand, fescue species may provide the potential source for improvement of the grassland cultivars.

Both genera are phylogenetically related, with ryegrasses presumably having evolved from meadow fescue
(F. pratensis Huds.) about 3 million years ago (Catalan et al. 2004). Due to this relatively close relatedness, species of fescues and ryegrasses are crossable and their hybrids have been found in nature. In breeding programs, targeted crosses of selected fescue and ryegrass species gave arise to Festulolium cultivars (Ghesquiere et al. 2010) with various genome composition (Kopecký et al. 2006). These hybrids may combine high persistence and abiotic-stress tolerance of fescues with high yield and feeding quality of ryegrass. In the past, the most frequently used cross combination was L. multiflorum pollinated with F. pratensis (reviewed in Kopecký et al. 2008). However, due to the relatively low drought tolerance of both parental species, this trait is not sufficiently expressed in such hybrids. For that reason, selection of suitable drought tolerant fescues for crosses with ryegrasses can considerably increase the efficiency of Festulolium breeding in the future. Newly released hybrids can replace pure ryegrass and Festulolium cultivars and increase yields of grass mixtures in dry conditions while maintaining similar animal feeding quality.

The aim of this work was to estimate the potential of various fescue species to withstand periods of dry and hot summer weather. We estimated their drought tolerance and subsequent regrowth ability in six fescue (sub)species, two ryegrass species and several Festulolium hybrids during three years under semi-controlled conditions. This is the first such multi-species phenotyping for drought in the Festuca-Lolium complex and as a preliminary study is quite rudimentary. On the other hand, the experiments were from the start planned with breeder needs in mind, and so strict layouts and designs with proper statistical treatment of the results, or providing functional analyses of the molecular or physiological mechanisms of the plant responses to drought stress were not among the goals. We are aware that our results can be only indicative and further validation is desirable. However, we believe that they provide some valid insight of the drought-tolerance potential of the species and hybrids within the FestucaLolium complex.

\section{Materials and methods}

Plants: We selected 48 genotypes to assess drought tolerance and drought recovery rates in each year (only 24 genotypes in 2019). Some of the genotypes were used repeatedly. The genotypes included cultivars of perennial ryegrass (L. perenne L.), Italian ryegrass (L. multiflorum Lam.), meadow fescue (F. pratensis Huds.), and tall fescue (F. arundinacea Schreb.) and cultivars and breeding material of Fl. krasanii (L. multiflorum $\times$ F. arundinacea), $F l$. braunii (L. multiflorum $\times F$. pratensis), and Fl. loliaceum (L. perenne $\times F$. pratensis). Besides these, ecotypes of $F$. arundinacea subsp. glaucescens Boiss. (referred here as F. glaucescens), F. mairei St.-Yves, $F$. arundinacea subsp. atlantigena (St.-Yves) Auquier (referred here as $F$. atlantigena), and $F$. pratensis subsp. apennina De Not. (referred here as F. apennina) were also tested. All genotypes are listed in Table 1 Suppl. Each genotype (represented by a single plant) was cloned into 
12 plants and grown in growth chambers before being transplanted into the experimental greenhouses.

Field experiments and phenotyping: All genotypes were planted during late March/early April of each year into the eight experimental greenhouses $(2.5 \times 5.5 \mathrm{~m})$ at the Institute of Experimental Botany in Olomouc (Czech Republic). The soil type in the experimental greenhouses was Gleyic Fluvisol. The planting design in each greenhouse involved 12 genotypes, each represented by six clones planted in a row. Second replicates (in a different greenhouse) were planted in different order of the rows to minimize the possible effect of the position of genotypes within the greenhouse.

Drought was simulated during three successive years 2017 - 2019. In summer, once the plants were well developed, irrigation was withheld for five to seven weeks. The irrigation was restarted based on visual observations of severe defects of plants and once the first clones started dying. Visual observations were made once a week starting on the day when irrigation was stopped, during the drought and recovery period, and finished about 5 - 7 weeks after the restart of irrigation. Visual scoring was from 9 (vigorous healthy plant) to 1 (plant death). In 2017, the simulated drought period started on July 22, recovery period with irrigation started on August 30, and the experiment was terminated on October 3. In 2018, the drought period started on June 8, recovery period started on August 10, and the last scoring was on October 5. In 2019 , the drought period started on July 1, recovery period started on August 19, and the last scoring date was October 7 . Temperatures during the experiment are given in Table 2 Suppl.

In the years 2017 and 2018, there was no precipitation, or precipitation was low, during the drought period and plant performance was not affected by precipitation outside the greenhouses. In the year 2019, several rains appeared in the period of simulated drought. It was clearly evident that plants close to the greenhouse walls performed much better than the plants from inner parts of the greenhouses. For that, the two plants affected by the precipitation out of the greenhouse were discarded from the further calculations.

The performance of each genotype during drought and recovery periods was expressed as the difference (in percentage) of the score (average for 12 clones) on a particular scoring date from the initial score.

\section{Results and discussion}

All entries in the experiments differed significantly in their reaction to drought and in the regrowth capacity. The most drought-tolerant species were $F$. glaucescens, F. mairei, and $F$. atlantigena in all years of the study (Fig. 1). These three species continued to grow during the first three weeks of the imposed drought, followed by stagnation (but not decline) during the rest of the drought period. Once irrigation was restarted, they initiated regrowth leading to full vigour at the end of the scoring period.
This is not surprising as these species naturally grow in habitats with low or uneven precipitation in Northern Africa (all species), Spain and France (F. glaucescens) (Devesa et al. 2013). Unfortunately, these species are not particularly suitable per se in agricultural production due to a low rate of establishment and of leaf growth, a low dry matter production and low feeding quality compared to traditional agricultural grass species. In addition, rigid, highly-lignified leaves, typical of all three species, additionally reduces their feeding value and palatability (Ghesquiere et al. 1996). On the other hand, they might be utilized for intergeneric hybridization with ryegrass species. Such an approach has already been applied in breeding of French cultivars Lueur, Lusilium, and Luxane (Ghesquiere et al. 2010). However, these cultivars were not primarily selected for drought tolerance and further selection would be necessary to develop cultivars with significantly improved drought tolerance. Cultivar Lueur has been evaluated in the EUCARPIA Festulolium Working group multi-site field trial and displayed a similar reaction to drought stress in the Czech Republic to that of tall fescue cv. Kora (V. Černoch, pers. comm.). High variability in genome composition of L. multiflorum $\times$ $F$. glaucescens cultivars gives hope that improved drought tolerance similar or close to that of $F$. glaucescens might be achieved in future. Ghesquiere et al. (1996) were able to select genotypes of these hybrids with improved palatability, up to that of the highest ranked tall fescues, far exceeding pure $F$. glaucescens. Intergeneric hybridization between ryegrasses and $F$. mairei has been used in the breeding program of IBERS in Wales, and the hybrids displayed improved ruminal nitrogen-use efficiency in feeding of grazing cattle due to higher conversion rates of nitrogen into microbial protein (Kamau et al. 2018).

Tall fescue ( $F$. arundinacea) is reported as the most drought tolerant grass with forage and turf utilization within the Festuca-Lolium complex. Using a combined approach of rainout shelters and hydroponic system with polyethylene glycol, Bothe et al. (2018) showed that tall fescue outperformed diploid meadow fescue and perennial ryegrasses in drought tolerance. This is in agreement with our results, as $F$. arundinacea outperformed diploid meadow fescues, Italian ryegrass, and to some extent also perennial ryegrasses. Good drought tolerance in tall fescue populations was also apparent in a study by Ebrahimiyan et al. (2012). On the other hand, accessions of tetraploid meadow fescue outperformed tall fescues during drought stress, but did not have as much ability to regrowth as tall fescues (Bothe et al. 2018). In our study, we observed rapid regrowth of tetraploid meadow fescues after the restart of irrigation (see below). Tall fescue genotypes used in our study performed with no or only marginal decay during the drought period and substantial regrowth after the restart of irrigation. Among tall fescues, the highest potential as a source of drought tolerance has the Mediterranean morphotype. An accession of this morphotype was tested in 2018 and it withstood drought and provided regrowth similar to $F$. atlantigena. This morphotype is characterized by summer dormancy as a drought avoidance mechanism and exhibits greater growth during autumn (Dierking et al. 


\section{5, Kopecký et al. 2019b).}

During the first year (2017), we observed that a tetraploid cultivar of $F$. pratensis performed much better than diploid cultivars (Fig. $2 A$ ). The tetraploid performed even better during the drought period than $F$. arundinacea itself, and showed decline only in the last week of the drought stress, followed by rapid regrowth after irrigation restarted. On the contrary, diploid genotypes suffered early on from the drought stress period, and their regrowth was very slow relative to all other entries. Therefore, in the second year of the experiment (2018) we tested more tetraploid genotypes (three cultivars). All three tetraploid $F$. pratensis cultivars outperformed all three diploid cultivars during both the drought and the recovery periods and thereby confirming observations from 2017. This is not entirely surprising; polyploids are frequently found in extreme environments, perhaps as a consequence of a higher colonization ability, greater stress resistance, and broader ecological tolerance relative to their diploid progenitors (Stebbins 1984, Te Beest et al. 2012). This is likely caused by the neofunctionalization (acquiring a new function) of the duplicated genes, a phenomenon often observed after whole genome duplication events (Parisod et al. 2010). For example, autotetraploid genotypes of sea barley (Hordeum marinum subsp. gussoneanum) had significantly higher drought tolerance relative to diploids presumably due to a higher efficiency of the saccharide synthesis and energy storage due to higher photosynthetic rate in autotetraploids (Zhou et al. 2019). Similarly, Xu et al. (2019) simulated drought stress using the polyethylene glycol solution in clones of poplar (Populus ussuriensis) with different ploidy and observed that the triploids had the highest drought tolerance followed by tetraploids and diploids. On the other hand, autotetraploidy did not significantly increase drought tolerance in Italian and perennial ryegrasses in our experiments (data not shown). This is in contrast of the study of Bothe et al. (2018), who reported a higher drought tolerance in tetraploid L. perenne than in its diploid accessions.

Considerable variation in drought tolerance was evident

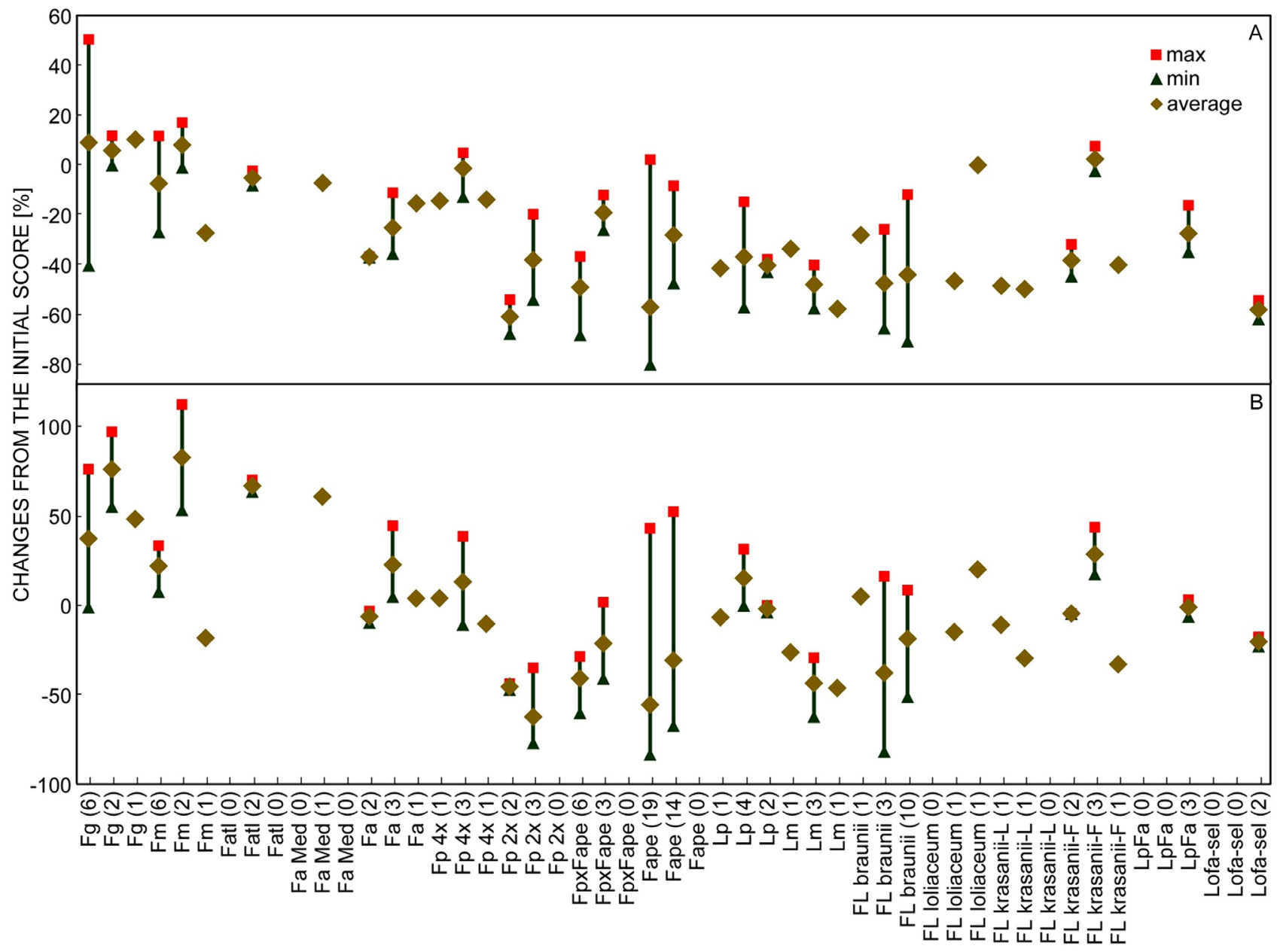

Fig. 1. Drought tolerance and recovery in grasses. Performance of the grass species within the Festuca-Lolium complex and their hybrids at the end of the drought stress period $(A)$ and at the end of the recovery period $(B)$ in three consecutive years $(2017-2019)$. The values represent changes of the score from the initial state on the day prior to the start of the drought stress period. Numbers of genotypes (in parentheses) varied between various species and years. Fg - F. glaucescens, Fm - F. mairei, Fatl - F. atlantigena, Fa Med F. arundinacea (Mediterranean morphotype), Fa - F. arundinacea (Continental morphotype), Fp - F. pratensis, FpxFape - triploid hybrid of $F$. pratensis $\times F$. apennina, Fape $-F$. apennina, Lp - L. perenne, Lm - L. multiflorum, FL - Festulolium, LpFa - hybrid of $L$. perenne $\times$ F. arundinacea, Lofa sel - selected plants of cv. Lofa. 
in F. apennina, an allotetraploid species naturally growing in Alpine and Apennine meadows. Generally, its tolerance to drought stress was poor and most accessions suffered during the drought period and did not recover well after re-watering (stagnated or showed reduced plant scores). However, a few genotypes had relatively good drought tolerance and good regrowth after re-watering (some $F$. glaucescens and $F$. mairei genotypes). During the first two years, we also explored a triploid hybrid of $F$. pratensis $\times$ F. apennina from Swiss Alpine meadows. These triploids showed about the same trend in their behaviour under drought stress and during the re-watering period as the parental species, meadow fescue and $F$. apennina. That is, they seriously suffered during drought stress and showed little or no regrowth once irrigation was restarted. On the other hand, slight heterosis for drought tolerance appeared among the triploids. We are aware that we did not compare the hybrids directly to their parents. However, the overall heterosis for this trait, as evidenced from mean scores for all genotypes of triploid hybrids and the $F$. pratensis and F. apennina accessions, was +124 and $+127 \%$ at the end of the drought stress period and +154 and $+181 \%$ at the end of the recovery period in 2017 and 2018, respectively. Extraordinary heterosis for annual biomass yield was observed in these triploid hybrids in our previous study, reaching up to $+508 \%$ (Boller and Kopecky, submitted). In this sense, it was mildly disappointing that heterosis for drought tolerance was only marginal. On the other hand, drought tolerance is probably not the key evolutionary trait of these hybrids, as they normally grow at sites with relatively often precipitation. Interestingly, the opposite trend was observed in meadow fescues: tetraploids showed higher drought tolerance relative to diploids, but similar or lower yield (V. Černoch, pers. comm.).

Italian and perennial ryegrasses showed distinctly different reactions (Fig. 2B). While both species suffered significantly during drought (especially at the end of the drought period), Italian ryegrass accessions were unable to recover well and stagnated in growth after the restart of irrigation, especially in 2018 and 2019. On the other hand, perennial ryegrasses showed an extraordinary recovery ability with very fast regrowth immediately after the restart of irrigation. At the end of the scoring period, their overall performance was similar to that of $F$. arundinacea accessions, which developed better during the period of drought. A high ability to recover after drought in perennial ryegrass has been described earlier (Cheplick et al. 2010, Turner et al. 2012, Bothe et al. 2018).

One of the main aims of this study was to evaluate the potential of various Festulolium hybrids (both cultivars and breeding lines) to combine or introgress stress-related traits from fescues into high yielding and nutritious ryegrasses. Data show that Italian ryegrass cultivars suffer significantly under drought. It was not surprising, as selection during breeding of these cultivars was focused on yield characteristics, and no drought tests were included during the breeding process. Thus, any improvement in drought tolerance might increase their utilization in the near future with the predicted climate conditions with frequent mid-term periods of drought. Such introgression

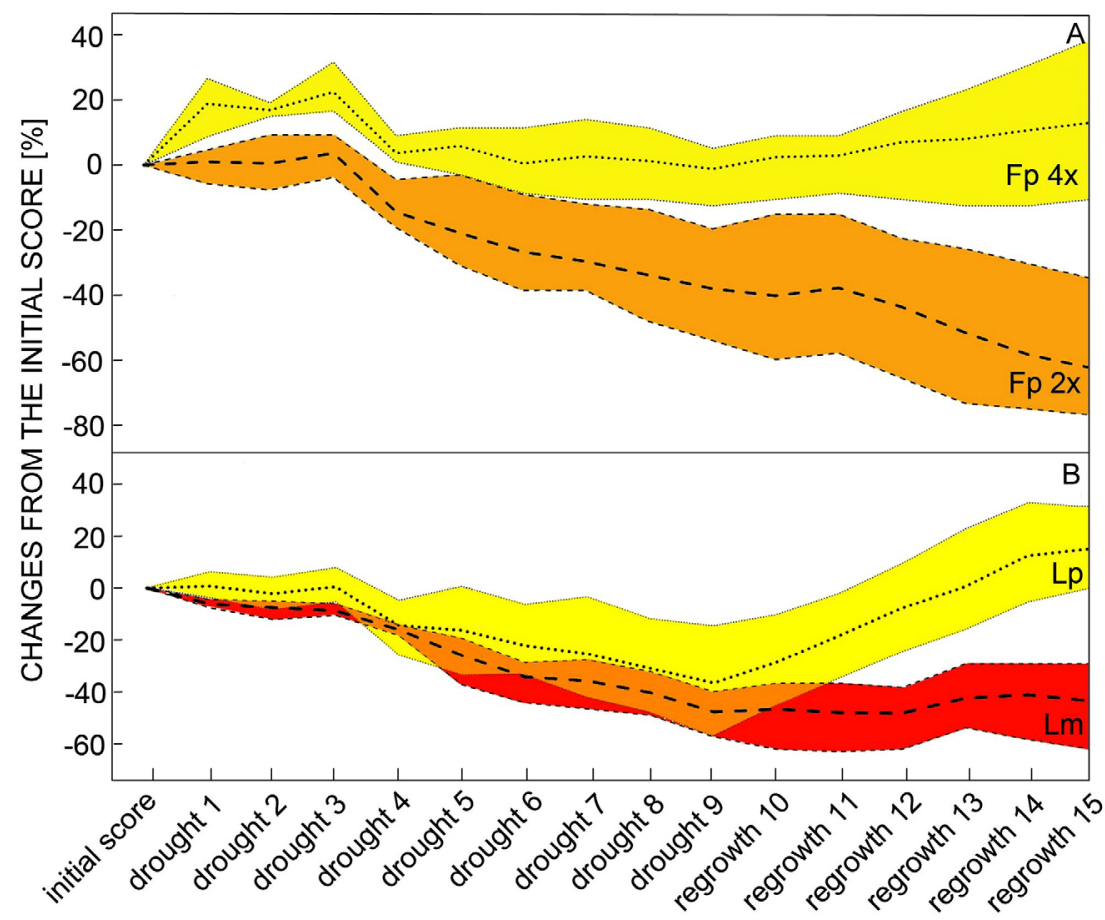

Fig. 2. The performance of the plants under drought stress and during a recovery period in summer 2018 with one-week intervals. $A$ - diploid accessions of meadow fescue (orange) suffered much more than autotetraploids (yellow), and their recovery was also worse. $B$ - both ryegrasses performed similarly under the drought stress, however, perennial ryegrass (yellow) recovered much better after restart of irrigation compared to Italian ryegrass (red). The colored areas represent values between maximum and minimum scores of the particular species, and the bolded line shows a mean score (all as percentages of the change from the initial score). Fp 2x - diploid meadow fescue, $\mathrm{Fp} 4 \mathrm{x}$ - autotetraploid meadow fescue, Lm - Italian ryegrass, Lp - perennial ryegrass. 
might be beneficial even if it also (slightly) negatively affects some yield characteristics. This would provide farmers a safer strategy of yield stability, even if at a somewhat lower fodder yield. There are several studies reporting successful introgressions of drought tolerance from $F$. mairei into $L$. perenne and from $F$. glaucescens and F. arundinacea into L. multiflorum (Cao et al. 2003, Humphreys et al. 2005, reviewed in Kopecký et al. 2008). However, these attempts did not result in new cultivar releases, perhaps for two reasons. Linkage drag associated with interspecific hybridization hampers sufficient yield production and other key characters in the forage business, or the introgressions were not stable. Instability and elimination of $F$. pratensis chromatin introgressed into L. multiflorum has been observed in cultivars of $\mathrm{Fl}$. braunii (Kopecký et al. 2019a).

In this study, the highest potential seems to be in the Fl. krasanii (tall fescue-type) cultivars: [L. multiflorum $\times$ $F$. arundinacea $] \times F$. arundinacea. Three entries showed the same or very similar trends as tall fescues in all three years of the study. They generally showed minimal or no damage caused by drought, with slow development after the irrigation re-start. A wide range of variation in drought tolerance was evident among cultivars of $F l$. braunii (L. multiflorum $\times F$. pratensis) and $F l$. loliaceum (L. perenne $\times F$. pratensis). They generally followed the trends of their parents - meadow fescue and ryegrasses. Generally, genotypes of $\mathrm{Fl}$. braunii showed similar development to that of L. multiflorum, but some of them showed significantly less damage under drought, with better regrowth after the restart of irrigation. Genotypes of $\mathrm{Fl}$. loliaceum followed the pattern of their L. perenne parent, with good regrowth during the recovery period.

The end-users, such as farmers, should also consider what strategies are more suitable for their grass field utilization and economics; either good maintenance of the biomass production under moderate water limitation, or drought survival with no or minor productivity during severe drought but good recovery after rehydration (Bothe et al. 2018). If the first one is the goal, wild species with extraordinary drought tolerance, such as $F$. mairei and $F$. glaucescens should be included either in mixtures (after selection for the genotypes with improved yield and digestibility) or as potential parents for interspecific hybridization with ryegrass species. Fl. krasanii (tall fescue-types) seems to be also a good potential source for the improvement of tall fescues. Better digestibility of some of $F$. krasanii cultivars brings the possibility to replace pure tall fescue cultivars and the increase the feeding value of grass mixtures (V. Černoch, pers. comm.). If the minor or no productivity during severe drought but a good recovery after rehydration is the key character, selections from perennial ryegrass, $F l$. loliaceum (L. perenne $\times$ $F$. pratensis) and $F l$. braunii (L. multiflorum $\times$ F. pratensis) with high heterosis for this trait in some genotypes would be probably the most suitable option. However, perennial ryegrasses (and presumably $\mathrm{Fl}$. braunii and $\mathrm{Fl}$. loliaceum) will suffer under the anticipated climate conditions, as modelled by Lee et al. (2019). Therefore, efforts made into interspecific hybridization of perennial ryegrasses with drought tolerant fescues should be seriously considered.

Drought tolerance is a complex trait with various mechanisms used by plant species to cope with the water deficiency (Mickelbart et al. 2015). They can be divided into short-term responses such as stomatal closure and decreased $\mathrm{C}$ assimilation in leaves, inhibition of growth in shoots and osmotic adjustment in roots and long-term responses including reduced transpiration area, metabolic acclimation, sustained root growth, and increased root/ shoot (Chaves et al. 2003). The research on drought tolerance is primarily focused on the identification of tolerant lines and uncover the genes/QTLs and mechanisms involved in cellular and whole-plant responses. A QTL for long-term drought tolerance was identified on chromosome 3F of F. pratensis (Alm et al. 2011). Several other studies suggest that this genome region is an excellent source of tolerance towards drought stress (Kosmala et al. 2003, Humphreys et al. 2005). The coincident location of several stress tolerance QTL in Festuca with QTL and genes in Triticeae species, notably dehydrins, CBF transcription factors and vernalisation response genes indicate the action of structural or regulatory genes conserved across evolutionarily distant species (Alm et al. 2011).

To conclude, our results, as preliminary as they are, indicate a wide range of variation for drought tolerance and after-drought recovery within the species of the Festuca-Lolium complex. It appears that species-diverse swards may improve the grassland resilience to changing climatic conditions (MacDougall et al. 2013). Indeed, high biomass systems with low diversity of species showed a greater biomass reduction in response to drought than low multi-species biomass systems did (Wang et al. 2007). As such, species mixtures are believed to perform best under climate change (Kipling et al. 2016). Together with the development of the interspecific hybrids, exhibiting heterosis for drought tolerance (and presumably various yield-related traits) species mixtures would be another way of mitigating the impacts of climate change on grassland communities in the near future. Wild polyploid species F. glaucescens, F. mairei, and F. atlantigena appeared here as the most promising components for intergeneric hybridization with ryegrasses (presumably perennial ryegrass). Successful introgression of drought tolerance was confirmed among the $F l$. krasanii accessions (L. multiflorum $\times F$. arundinacea hybrids), which in association with higher digestibility may possibly replace pure tall fescue cultivars and increase the feeding value of grass mixtures. Similarly, large variability for drought tolerance and after-drought recovery in $F l$. braunii (L. multiflorum $\times F$. pratensis hybrid) and Fl. loliaceum (L. perenne $\times F$. pratensis hybrid) can allow selection of genotypes outperforming original L. multiflorum and L. perenne cultivars. Apart from those, new interspecific hybrids of ryegrasses with drought tolerant fescues should be explored to mitigate the impacts of climate change. Changed climate with more frequent extreme events, including agriculturally most demanding periods of droughts, will significantly affect grassland productivity, and hence may menace the food security and the continuity of supply from grassland systems (Kipling et al. 2016). 
Thus, identification of new sources of drought tolerance among wild relatives of crops and better understanding of the molecular and physiological mechanisms involved in plant ability to withstand drought stresses are of urgent need.

\section{References}

Alm, V., Busso, C.S., Ergon, A., Rudi, H., Larsen, A., Humphreys, M.W., Rognli, O.A.: QTL analyses and comparative genetic mapping of frost tolerance, winter survival and drought tolerance in meadow fescue (Festuca pratensis Huds.). Theor. appl. Genet. 123: 369-382, 2011.

Bothe, A., Westermeier, P., Wosnitza, A., Willner, E., Schum, A., Dehmer, K.J., Hartmann, S.: Drought tolerance in perennial ryegrass (Lolium perenne L.) as assessed by two contrasting phenotyping systems. - J. Agron. Crop Sci. 204: 375-389, 2018.

Cai, X. M., Zhang, X., Noel, P.H., Shafiee-Jood, M.: Impacts of climate change on agricultural water management: a review. - Wiley Interdisciplinary Reviews - Water 2: 439-455, 2015.

Cao, M., Bughrara, S. S., Sleper, D. A.: Cytogenetic analysis of Festuca species and amphiploids between Festuca mairei and Lolium perenne. - Crop Sci. 43: 1659-1662, 2003.

Catalan, P., Torrecilla, P., Rodriguez, J. A. L., Olmstead, R. G.: Phylogeny of the festucoid grasses of subtribe Loliinae and allies (Poeae, Pooideae) inferred from ITS and trnL-F sequences. - Mol. Phylogen. Evol. 31: 517-541, 2004.

Chaves, M.M., Maroco, J., Pereira, J.S.: Understanding plant responses to drought - from genes to the whole plant. - Funct. Plant Biol. 30: 239-264, 2003.

Cheplick, G.P., Perera, A., Koulouris, K.: Effect of drought on the growth of Lolium perenne genotypes with and without fungal endophytes. - Funct. Ecol. 14: 657-667, 2000.

Devesa, J.A., Catalán, P., Müller, J., Cebolla, C., Ortúñez, E.: Checklist of Festuca L. (Poaceae) in the Iberian Peninsula. Lagascalia 33: 183-274, 2013.

Dierking, R., Azhaguvel, P., Kallenbach, R., Saha, M., Bouton, J., Chekhovskiy, K., Kopecky, D., Hopkins, A.: Linkage maps of a mediterranean $\times$ continental tall fescue population and their comparative analysis with other Poaceae species. - Plant Genome 8: 1-18, 2015.

Ebrahimiyan, M., Majidi, M. M., Mirlohi, A., Gheysari, M.: Drought-tolerance indices in a tall fescue population and its polycross progenies. - Crop Pasture Sci. 63: 360-369, 2012.

Eitzinger, J., Trnka, M., Semeradova, D., Thaler, S., Svobodova, E., Hlavinka, P., Siska, B., Takac, J., Malatinska, L., Novakova, M. Dubrovsky, M., Zalud, Z.: Regional climate change impacts on agricultural crop production in Central and Eastern Europe - hotspots, regional differences and common trends. - J. agr. Sci. 151: 787-812, 2013.

Eitzinger, J., Utset, A., Trnka, M., Zalud, Z., Nikolaev, M., Uskov, I.: Weather and climate and optimization of farm technologies at different input levels. In: Sivakumar, M.V.K., Motha, R.P. (ed.): Managing Weather and Climate Risks in Agriculture. Pp. 141-170. Springer-Verlag, Berlin - Heidelberg 2007.

Ghesquiere, M., Emile, J. C., Jadas Hecart, J., Mousset, C., Traineau, R., Poisson, C.: First in vivo assessment of feeding value of Festulolium hybrids derived from Festuca arundinacea var. glaucescens and selection for palatability. Plant Breed. 115: 238-244, 1996.

Ghesquiere, M., Humphreys, M. W., Zwierzykowski, Z.: Festulolium. - Fodder Crops Amenity Grasses 5: 293-316, 2010.
Harle, K.J., Howden, S.M., Hunt, L.P., Dunlop, M.: The potential impact of climate change on the Australian wool industry by 2030. - Agr. Syst. 93: 61-89, 2007.

Hulke, B.S., Watkins, E., Wyse, D., Ehlke, N.: Winterhardiness and turf quality of accessions of perennial ryegrass (Lolium perenne L.) from public collections. - Crop Sci. 47: 1596$1602,2007$.

Humphreys, J., Harper, J. A., Armstead, I. P., Humphreys, M. W.: Introgression-mapping of genes for drought resistance transferred from Festuca arundinacea var. glaucescens into Lolium multiflorum. - Theor. appl. Genet. 110: 579-587, 2005.

Kamau, S., Belanche, A., Humphreys, M., Kingston-Smith, A.: Manipulation of rumen nitrogen flows by use of Festulolium hybrids in rumen simulation fermenters. - In: Brazauskas, G., Statkevičiute, G., Jonavičiene, K. (ed.): Breeding Grasses and Protein Crops in the Era of Genomics. Pp. 121-124. Springer International Publishing, Cham 2018.

Kipling, R.P., Virkajaervi, P., Breitsameter, L., Curnel, Y., De Swaef, T., Gustavsson, A.M., Hennart, S., Hoglind, M., Jaervenranta, K., Minet, J., Nendel, C., Persson, T., PiconCochard, C., Rolinski, S., Sandars, D.L., Scollan, N.D., Sebek, L., Seddaiu, G., Topp, C.F.E., Twardy, S., VanMiddelkoop, J., Wu, L., Bellocchi, G.: Key challenges and priorities for modelling European grasslands under climate change. - Sci. total Environ. 566: 851-864, 2016.

Kopecky, D., Horakova, L., Duchoslav, M., Dolezel, J.: Selective elimination of parental chromatin from introgression cultivars of $\times$ Festulolium $($ Festuca $\times$ Lolium $)$. - Sustainability 11: 3153, 2019a.

Kopecky, D., Loureiro, J., Zwierzykowski, Z., Ghesquiere, M., Dolezel, J.: Genome constitution and evolution in Lolium $\times$ Festuca hybrid cultivars (Festulolium). - Theor. appl. Genet. 113: 731-742, 2006.

Kopecky, D., Lukaszewski, A. J., Dolezel, J.: Cytogenetics of Festulolium (Festuca $\times$ Lolium hybrids). - Cytogenet. Genome Res. 120: 370-383, 2008.

Kopecky, D., Talukder, S.K., Zwyrtkova, J., Trammell, M., Dolezel, J., Saha, M.C.: Inter-morphotype hybridization in tall fescue (Festuca arundinacea Schreb.): exploration of meiotic irregularities and potential for breeding. - Euphytica 215: 97, 2019b.

Kosmala, A., Skibinska, M., Zwierzykowski, Z., Humphreys, M.W., Rapacz, M., Joks, W.: Introgression of genes for abiotic stress resistance from Festuca pratensis and F. arundinacea into Lolium multiflorum germplasm. - Vortr. Pflanzenzüchtg. 59: 225-231, 2003.

Lee, M. A., Howard-Andrews, V., Chester, M.: Resistance of multiple diploid and tetraploid perennial ryegrass (Lolium perenne L.) varieties to three projected drought scenarios for the UK in 2080. - Agronomy 9: 159, 2019.

MacDougall, A.S., McCann, K.S., Gellner, G., Turkington, R.: Diversity loss with persistent human disturbance increases vulnerability to ecosystem collapse. - Nature 494: 86-89, 2013.

Mickelbart, M.V., Hasegawa, P.M., Bailey-Serres, J.: Genetic mechanisms of abiotic stress tolerance that translate to crop yield stability. - Nature Rev. Genet. 16: 237-251, 2015.

O'Mara, F.P.: The role of grasslands in food security and climate change. - Ann. Bot. 110: 1263-1270, 2012.

Parisod, C., Holderegger, R., Brochmann, C.: Evolutionary consequences of autopolyploidy. - New Phytol. 186: 5-17, 2010.

Stebbins, G.L.: Polyploidy and the distribution of the arcticalpine flora - New evidence and a new approach. - Bot. helvetica 94: 1-13, 1984.

Te Beest, M., Le Roux, J. J., Richardson, D. M., Brysting, A. K., 
Suda, J., Kubesova, M., Pysek, P.: The more the better? The role of polyploidy in facilitating plant invasions. - Ann. Bot. 109: 19-45, 2012.

Trnka, M., Kersebaum, K.C., Eitzinger, J., Hayes, M., Hlavinka, P., Svoboda, M., Dubrovsky, M., Semeradova, D., Wardlow, B., Pokorny, E., Mozny, M., Wilhite, D., Zalud, Z.: Consequences of climate change for the soil climate in Central Europe and the central plains of the United States. - Climatic Change 120: 405-418, 2013.

Turner, L.R., Holloway-Phillips, M.M., Rawnsley, R.P., Donaghy, D.J., Pembleton, K.G.: The morphological and physiological responses of perennial ryegrass (Lolium perenne L.), cocksfoot (Dactylis glomerata L.) and tall fescue (Festuca arundinacea Schreb.; syn. Schedonorus phoenix Scop.) to variable water availability. - Grass Forage Sci. 67: 507-518, 2012.

Wang, Y.F., Yu, S.X., Wang, J... Biomass-dependent susceptibility to drought in experimental grassland communities. - Ecol.
Lett. 10: 401-410, 2007.

Xu, J.Q., Jin, J.J., Zhao, H., Li, K.L.: Drought stress tolerance analysis of Populus ussuriensis clones with different ploidies. - J. Forest. Res. 30: 1267-1275, 2019.

Zahradnicek, P., Trnka, M., Brazdil, R., Mozny, M., Stepanek, P., Hlavinka, P., Zalud, Z., Maly, A., Semeradova, D., Dobrovolny, P., Dubrovsky, M., Reznickova, L.: The extreme drought episode of August 2011 - May 2012 in the Czech Republic. - Int. J. Climatol. 35: 3335-3352, 2015.

Zhao, G., Webber, H., Hoffmann, H., Wolf, J., Siebert, S., Ewert, F.: The implication of irrigation in climate change impact assessment: a European-wide study. - Global Change Biol. 21: 4031-4048, 2015.

Zhou, K., Liu, B.B., Wang, Y.L., Zhang, X.Q., Sun, G.L.: Evolutionary mechanism of genome duplication enhancing natural autotetraploid sea barley adaptability to drought stress. - Environ. exp. Bot. 159: 44-54, 2019. 